\title{
Electronic Education at the Faculty of Nuclear Sciences and Physical Engineering
}

\author{
D. Vaněček, V. Klement \\ This paper deals with the current issue of electronic education, and is based on a study of Internet support for education at the Faculty of Nu- \\ clear Sciences and Physical Engineering at the Czech Technical University in Prague. \\ The goal of the study was to establish to what extent and in what ways electronic support for education is utilized at FNSPE CTU. In order \\ to answer these questions, a questionnaire was conducted at the faculty. We will present the outcomes here.
}

Keywords: blended learning, LMS, FNSPE

\section{Electronic education}

\subsection{Introduction}

In the present-day education system, e-learning is a widely-used term referring to activities that can improve not only distance learning but also full-time study. It refers to a manner of education which enables learners to complement and support the standard education with the use of modern computer technology (in most cases of web technologies). E-learning is changing the view on current education, and has influenced even the most important pedagogical-psychological theories of learning connected with technologies. If proper procedures are observed while preparing a course, its application in education corresponds to modern conceptions of cognition: constructivism and connectivism. To the concepts of remembering, recalling, and learning are added the concepts of thinking, creating, and forming.

A proper e-learning course should consciously support internal, rather than external motivation of learners, and should accompany individual learning with cooperative learning. The main attributes of the course should be:

- Open learning materials connected to a number of expanding and elaborating texts.

- Methodological candor.

- A problem-solving approach that propounds alternative views and theories, and consequently places emphasis on critical and divergent thinking.

- Students can be included in preparing the content

\subsection{History}

Electronic education as it is known today is a relatively new way of delivering education. Its history started to be written only in the 1990s, alongside the development of the Internet. Nevertheless, if we take a broader definition of this notion, the first e-learning (in the sense of learning through technology) was through learning machines, the first of which was constructed already in the 1920 s by the psychologist S. L. Pressey. However, this machine did not come into its own. The next attempt at program learning appeared in the 1950s, and even came to the Czechoslovak Republic, where the Unitutor educational automaton was created. However not even these automata were successful, most probably as a result of their cost.

Foreign language teaching attempted to make use of each new development in audio and audiovisual technology in the $20^{\text {th }}$ century, but until quite late in the century high cost, user-unfriendliness and unsatisfactory auditory quality were considerable drawbacks.

The next milestone of e-learning was during the period of 1984 and 1993. An idea to support education by the use of personal computers arose with their development. It consisted mostly of distribution of educational content by floppy disks or CD-ROM, this manner of application is often called CBT (Computer Based Training). From the current point of view, this way of education has many problems, such as the inability to update the content of learning materials, or the fact that the student has no contact with a teacher or other students.

The history of the true e-learning starts after the year 1993 (although the term itself was not coined until 1999) alongside with the development of the web. At first there were only static sites, where learning materials were available, and communication with the teacher either did not take place at all, or only through e-mail. This phase is often called WBT (Web Based Training). Later, alongside with the development of Internet technologies, more elaborate courses have begun to appear, which enable better cooperation, contact with a teacher, and feedback. Moreover, also the content could stay up-to-date, due to easy updating of the sites, and become more and more multimedia.

Nowadays, e-learning has found its application not only in the educational system, but also in commercial firms, which use it in lifelong learning of their employees. As a result, there are thousands so-called Corporate Universities, which are one of the main driving forces of this method of learning.

Finally, the current situation in our country will be presented. First attempts to introduce e-learning appeared around the year 1999, and since then the number of projects dealing with this topic is increasing. Within the CTU the well-known conference Belcom also takes place. This conference is focused on monitoring of the new trends in the area of e-learning. 


\subsection{Definition}

Defining of the notion of e-learning proves to be difficult and disunited in spite of its high frequency of use. A number of definitions has arisen during the time of its existence, and many differ significantly from each other. The usual differences are whether it is a definition from a pedagogical or technological point of view, or whether older forms of usage of computers for education (especially CBT) belong to e-learning or whether e-learning means only the use of Internet technologies. For better understanding we will present some definitions of this notion by contemporary experts, see [1]:

- For me, e-learning is studying by the means of electronic media, let it be learning through CD or internet.

- By e-learning I understand educational and training systems (especially on-line ones).

- I understand e-learning to be an education supported by modern electronic means (computers, media, internet) in distant learning, combined and full-time study.

- I imagine e-learning to be an electronic education, i.e. educational course created in LMS which is intended for self-study under supervision of a teacher who communicates with a student in an electronic manner through this environment.

Experts in their definitions of e-learning mostly prefer its more sophisticated and more exacting form.

\subsection{Course creation}

Creating an e-learning course can prove rather difficult for many teachers. In order to create such a course it is necessary to be able to create a website. This requires knowledge of creation of html documents and in a case of websites with some active components also knowledge of programming e.g. in PHP. This is a big problem, because it cannot be expected that every teacher will be knowledgeable in the area of web technologies. Fortunately, so-called web content management systems (WCMS) can be used for creating of e-learning courses.

WCMS are nowadays one of the basic means used for website creation. They are mostly web applications (programs running on the Internet, which are approached through the browser) which enable almost anybody, even without any programming skills, to create and maintain websites. Their main purpose is to enable a visitor to $\log$ in and to add some text or other content, which will be saved and subsequently available for other users for viewing as a website (e.g. Wikipedia). However, they often involve advanced functions which would not be easy to create even for a skilled programmer. This includes various forums, discussions, inquiries and others (like e.g. on Facebook, which is a web application but not exactly WCMS). All these functions are moreover very well secured and debugged. For example Drupal, Joomla, or other systems on the basis of Wiki belong among popular management systems.

From that it was just a small step to utilize such systems for education-oriented website creation, and thus developed so-called LCMS (Learning Content Management Systems). They differ from ordinary WCMS by their specialization on creation of specific sites (educational online courses) and by adding some functions specific for education. Besides
LCMS there exist LMS (Learning Management Systems). These systems do not serve to creating e-learning courses but to their operating and management. LMS thus enable to for example, follow results of individual students, appointing homework, or making available parts of courses created in advance in LCMS. It should be noted that many applications fulfill both roles. The best known LMS/LCMS in the Czech Republic is probably Moodle (see [2]).

\subsection{Utilization of e-learning at universities}

E-learning is being integrated as a part of education at many Czech universities and is created and run by LCMS/LMS systems. This integration of electronic education is at the present time of three types: (see [3])

- Electronic support of full-time study, classic education is mixed with elements of individual work of a student with electronic sources.

- Interactive elements are added to electronic support, classic education is in some cases limited.

- Student gets access to electronic courses, and whole educational cycles. Classic education is limited to minimum, or it is omitted completely. Electronic support is highly interactive and even tests of knowledge are often realized this way.

\section{Research of current electronic support of education at FNSPE}

\subsection{Faculty of Nuclear Sciences and Physical Engineering}

Our research of utilization of Internet support of education was conducted at the Faculty of Nuclear Sciences and Physical Engineering. We tried to determine how e-learning is being used here nowadays, which means are used in its creation, and how students and teachers see its future development.

\subsection{History of the faculty}

It is one of the smaller faculties at Czech Technical University in Prague. It was founded as a part of the Czechoslovak nuclear program in 1955 under Charles University in Prague as a Faculty of Technical and Nuclear Physics. However, it quickly expanded its sphere of activity to a wide range of mathematical, physical, and chemical subjects. By government order of $12^{\text {th }}$ August of 1959 the faculty was transferred from Charles University to Czech Technical University as its fourth faculty and was renamed to Faculty of Nuclear Sciences and Physical Engineering.

Studying at the faculty is generally considered to be very demanding, but due to the small number of students they get almost individual care, especially during the higher grades. The Faculty offers various subjects to study, but only as full-time. As a matter of interest, the Faculty is in possession of its own nuclear reactor VR-1 (called "Vrabec", i.e. "Sparrow") which was put into operation in 1990 .

\subsection{Methodology and form}

Inquiries were divided into two groups. One for students, and one for the staff who uses Internet support. Because 
Internet support systems differ department from department (sometimes even within a department), one teacher was chosen from each department to answer this inquiry.

Inquiries for teachers were realized in a form of an interview, students could either fill out their inquiries online or some were handed printed copies.

\subsection{Results from the staff}

The inquiry was undertaken at six departments and as a result six members of the staff answered it. It is apparent from the results that almost all departments have their own servers and web space where teachers can upload materials for their courses. However, manners of execution vary greatly. Nevertheless, they can be divided into three groups:

- Teachers have web space assigned to them, they create websites on their own (or with the help from students).

- Teachers give materials they want to put on web to a server administrator who puts them online.

- Teachers use some management systems for web site creation.

Concerning management systems, they are used approximately by half of the departments, when one uses specifically LMS. However, general knowledge about the existence of LMS is relatively low, they often have only a vague idea that something like this exists. On the other side, almost everyone knew what management system is.

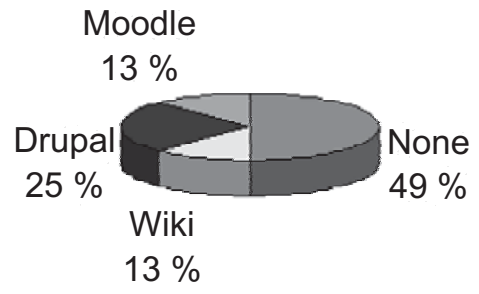

Fig. 1: Chart shows which WCMS are used and their distribution

Concerning e-learning, opinions were rather skeptical. A great number of teachers sees behind this notion just a replacement of a classic education in a form of presentations which are available somewhere on the Internet. They do not consider this, understandably, as an improvement in education. Consequently, pure electronic form of education instead of a classic one was renounced by almost everyone. On the other side, using websites as a support of lectures, according to the majority, makes sense. Nonetheless, they mostly consider it as time-consuming and technically demanding. Some of the teachers see e-learning as a convenient variant for postgradual students and lifelong learning systems in the future.

\subsection{Results from students}

142 students from all grades of both bachelor and master study have participated in the inquiry. First, we will deal with the question of how often students encounter Internet support of education.

\section{Without internet support $69 \%$}

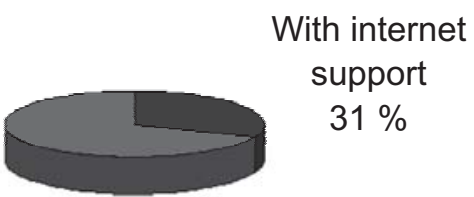

Fig. 2: Chart shows an average use of e-learning during classes according to students

The results (Fig. 2) showed that approximately each third subject already has some sort of internet support. Therefore, this manner of support is relatively used at the faculty and thus the inquiry itself makes sense.

When we look at the question dealing with content of the websites (Table 1), we see that majority consists of static elements such as study materials, exercises, news from the subject, and links to other sites with similar content. Whereas assigning homework through the web, forum, or interactive tests are rather rare. The most common feature is study materials.

Let us concentrate on the quality of these materials. This question is answered by the following chart. From it we can see that if there are any materials, then the materials are of good quality and cover the whole subject. On the other side, it is very rare that these materials bring something new to the subject and they are often just presentations from lectures.

As a matter of interest, we tried to find out what students do with electronic materials. Here the results (fig. 4) showed that the majority of students print their materials, because reading from the monitor does not suit them.

Table 1: Tab shows how often specific elements of electronic support are used

\begin{tabular}{|l|c|c|c|c|c|c|}
\hline & $\begin{array}{c}\text { Never } \\
(\mathbf{\%})\end{array}$ & $\begin{array}{c}\text { Once } \\
\mathbf{( \% )}\end{array}$ & $\begin{array}{c}\text { Sometimes } \\
\mathbf{( \% )}\end{array}$ & $\begin{array}{c}\text { Often } \\
\mathbf{( \% )}\end{array}$ & $\begin{array}{c}\text { Almost always } \\
\mathbf{( \% )}\end{array}$ & $\begin{array}{c}\text { Always } \\
(\mathbf{\%})\end{array}$ \\
\hline News from subject & 10.00 & 20.00 & 51.00 & 15.00 & 3.00 & 1.00 \\
\hline Study materials & 0.00 & 13.00 & 30.00 & 41.00 & 11.00 & 5.00 \\
\hline Related links & 12.00 & 17.00 & 46.00 & 15.00 & 6.00 & 4.00 \\
\hline Forum & 69.00 & 17.00 & 9.00 & 4.00 & 0.00 & 1.00 \\
\hline Homework assigning & 15.00 & 26.00 & 36.00 & 19.00 & 4.00 & 0.00 \\
\hline Excersises & 6.00 & 11.00 & 64.00 & 19.00 & 0.00 & 0.00 \\
\hline Interactive tests & 84.00 & 16.00 & 0.00 & 0.00 & 0.00 & 0.00 \\
\hline
\end{tabular}




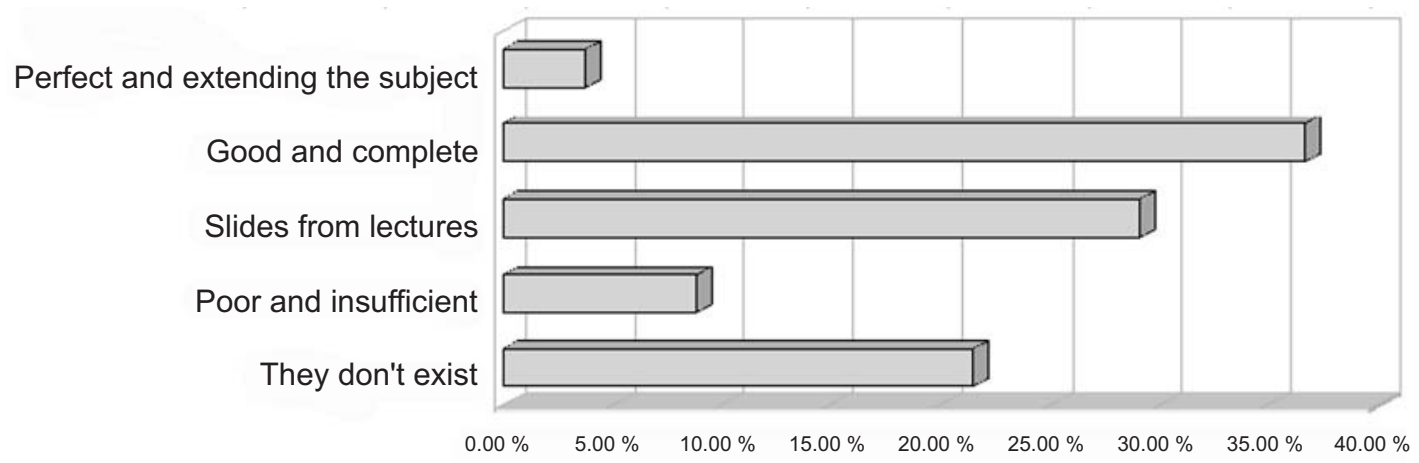

Fig. 3: Chart showing quality of electronic materials according to students

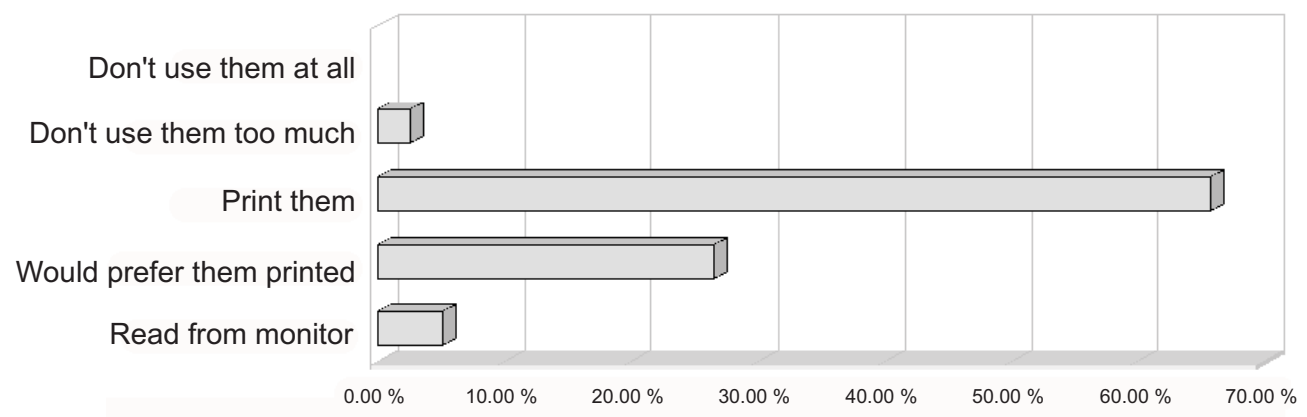

Fig. 4: Chart showing students' opinions on work with electronic materials

In the second part of the inquiry we explored what students think about e-learning and teaching based on e-learning.

First we inquired in which areas of subject e-learning could be used (Fig. 5). Programming oriented subjects absolutely won this question. Next followed the final question how students would envision integration of e-learning into study (Fig. 6). Here an option of a mere support won by majority, only some students would at best accept reduction of number of lectures per week, but students definitely do not want purely electronic form.

\section{Conclusion}

Internet support of education at FNSPE is not unknown. A lot of teachers at this faculty are skilled enough to create their own web support and they often do so. Moreover, at every department there is someone who is able to take care of

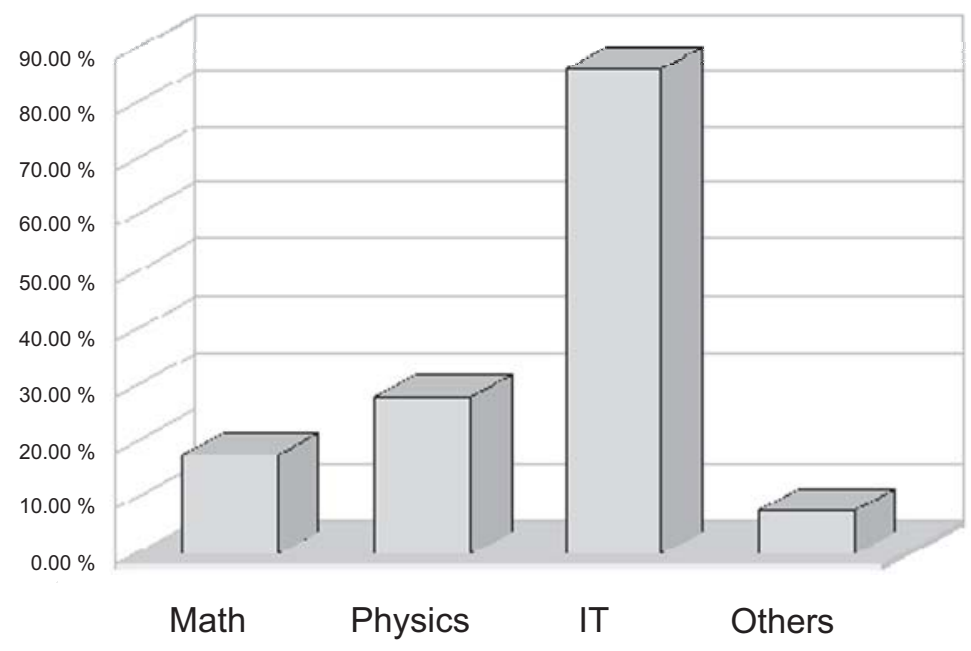

Fig. 5: Chart showing students' opinion on which fields of study are appropriate for e-learning (students could check multiple answers) 


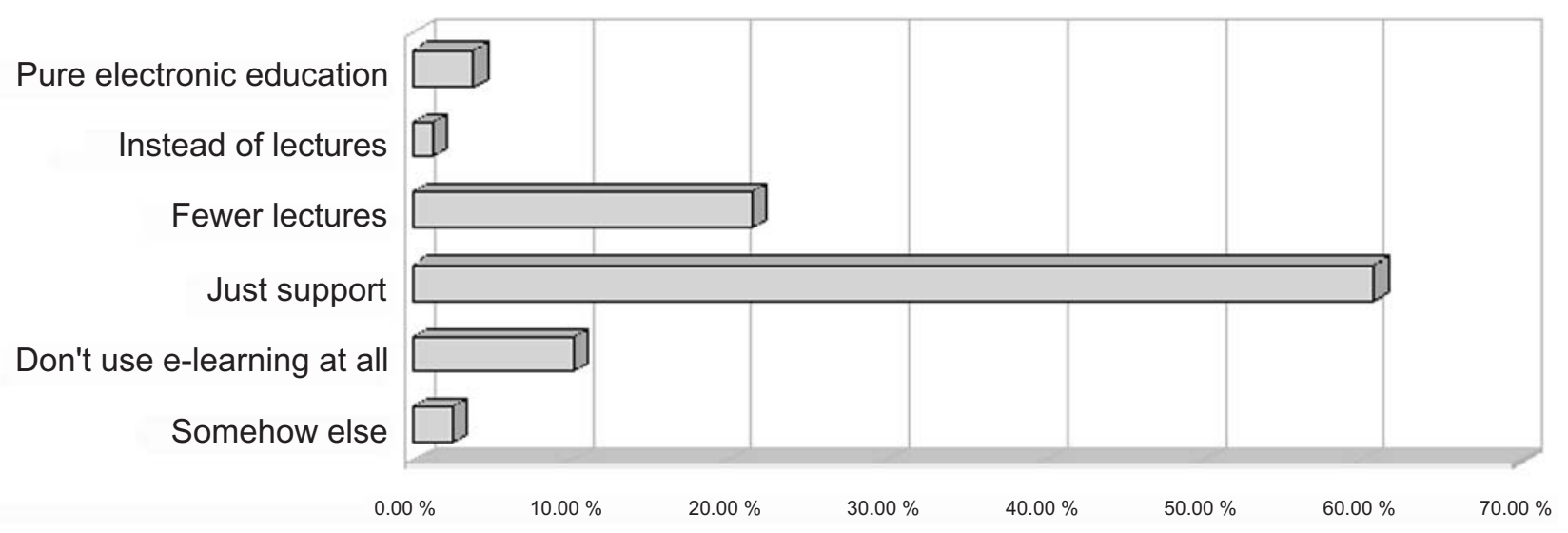

Fig. 6: Chart showing the best form of integration of e-learning into study according to students

web creation, if there are teachers unable to do it themselves. Concerning used technologies and space, almost all departments have their servers and do not use for web support means provided either by the faculty (unified web space) or by the university (LMS Moodle). In addition, half of the departments do not use any management systems and individual authors do not cooperate in any way. Thus web sites differ in visual, functional and technological aspects basically subject from subject.

Concerning opinions on e-learning and its utilization there is an agreement between students and teachers. Almost everyone agreed that Internet support has many advantages and should be used, but it should definitely remain only a support and classes should not become purely electronic.

\section{References}

[1] Sak, P., Skalková, J., Mareš, J.: Člověk a vzdělání v informačni společnosti. Praha: Portál, 2007. ISBN 978-80-7367-230-0.

[2] České stránky systému Moodle, http://moodle.cz/, [online].
[3] Rambousek, J.: E-learning z druhé strany. Zpravodaj ÚVT MU, 2003, roč. 8, č. 5. ISSN 1212-0901.

[4] Pejsar, Z.: Elektronické vzdělávání. Univerzita J. E. Purkyně v Ústí nad Labem, 2007. ISBN 978-80-7044-968-4.

[5] Vaněček, D.: Informačni a komunikačni technologie ve vzdělávání. Praha: ĆVUT, 2008. ISBN 978-80-01-04087-4.

Ing. Bc. David Vaněček, Ph.D.

e-mail: vanecek@muvs.cz

Czech Technical University in Prague Masaryk Institute of Advanced Studies

Horská 3

12800 Praha 2, Czech Republic

Bc. Vladimír Klement e-mail: klemevl1@fjfi.cvut.cz

Czech Technical University in Prague

Faculty of Nuclear Sciences and Physical Engineering Břehová 7

11519 Praha 1, Czech Republic 